\title{
ДЕМОГРАФИЧЕСКИЙ ДАЙДЖЕСТ
}

\author{
ИЛЬЯ КАШНИЦКИЙ, СОФЬЯ АХМАНАЕВА, АННА БЕЖАНИШВИЛИ, \\ НИКИТА ГАНЖА, ЮЛИЯ ЛОНЩИКОВА, ВАДИМ ХРЮКОВ
}

- Zhang, J. The Evolution of China's One-Child Policy and Its Effects on Family Outcomes

- Tropf, F. C., \& Mandemakers, J. J. Is the Association Between Education and Fertility Postponement Causal? The Role of Family Background Factors.

- Bongaarts, J., Mensch, B. S., \& Blanc, A. K. Trends in the age at reproductive transitions in the developing world: The role of education

- Wright, D. M., Rosato, M., \& O'Reilly, D. Influence of Heterogamy by Religion on Risk of Marital Dissolution: A Cohort Study of 20,000 Couples

- Reher, D., \& Requena, M. Elderly women living alone in Spain: the importance of having children

- Garcia-Roman, J., Flood, S., \& Genadek, K. Parents' time with a partner in a cross-national context: A comparison of the United States, Spain, and France

- Wahrendorf, M., Akinwale, B., Landy, R., Matthews, K., \& Blane, D. Who in Europe Works beyond the State Pension Age and under which Conditions? Results from SHARE

- Faggian, A., Rajbhandari, I., \& Dotzel, K. R. The interregional migration of human capital and its regional consequences: a review

- $\quad X u, X$., Li, Y., Liu, X., \& Gan, W. Does religion matter to corruption? Evidence from China

\section{THE EVOLUTION OF CHINA'S ONE-CHILD POLICY AND ITS EFFECTS ON FAMILY OUTCOMES}

[Zhang, J. (2017). The Evolution of China's One-Child Policy and Its Effects on Family Outcomes. Journal of Economic Perspectives, 31(1), 141-160. https://doi.org/10.1257/jep.31.1.141]

Еще в 1960 году коэффициент суммарной рождаемости в Китае был равен 5,7. К 2015 году этот показатель упал до 1,6 - ниже уровня таких стран как Франция или США. Существенное снижение, не правда ли? Многие исследователи связывают демографические изменения в КНР с законом 1979 года, вводившим ограничения на число детей, которое могла иметь одна семья: не более одного ребенка. Но только ли закон 1979 года оказал влияние на снижение уровня рождаемости, и какие еще последствия имели место после вступления в силу данного закона? На этот вопрос пытался найти ответы Чжан Цзюньсен в своей статье "Эволюция политики "Одна семья - один ребенок" в Китае и ее влияние на семьи".

\footnotetext{
ИЛЬЯ САВЕЛЬЕВИЧ КАШНИЦКИЙ (ilya.kashnitsky@gmail.com), НАЦИОНАЛЬНЫЙ ИССЛЕДОВАТЕЛЬСКИЙ УНИВЕРСИТЕТ «ВЫСШАЯ ШКОЛА ЭКОНОМИКИ», РОССИЯ; РНD КАНДИДАТ УНИВЕРСИТЕТА ГРОНИНГЕНА (RUG) И НИДЕРЛАНДСКОГО МЕЖДИСЦИПЛИНАРНОГО ДЕМОГРАФИЧЕСКОГО ИНСТИТУТА (NIDI).
}

СОФЬЯ АХМАНАЕВА, АННА БЕЖАНИШВИЛИ, НИКИТА ГАНЖА, ЮЛИЯ ЛОНЩИКОВА, ВАДИМ ХРЮКОВ, НАЦИОНАЛЬНЫЙ ИССЛЕДОВАТЕЛЬСКИЙ УНИВЕРСИТЕТ «ВЫСШАЯ ШКОЛА ЭКОНОМИКИ», РОССИЯ.

ОБЗОР ПОСТУПИЛ В РЕДАКЦИЮ В ФЕВРАЛЕ 2018 Г. 
Проблема "перенаселенности" все чаще и чаще стала волновать умы руководства Китайской народной республики, начиная с середины XX века. В 1955-1957 гг. председатель КНР Мао Цзэдун всерьез склонялся к принятию ряда шагов по сдерживанию уровня рождаемости. В 1958 г. его взгляды ненадолго претерпели радикальное изменение, когда рождаемость в стране резко упала в результате голода, вызванного последствиями Большого Скачка. Лидер КНР официально заявлял о преимуществах многочисленной нации, проводил курс на поддержку роста населения. Однако этот период продолжался недолго. Рождаемость в течение считанных лет отскочила к прежним высоким значениям, и уже в начале 1970-х гг. Мао вновь задумался о стимулировании снижения рождаемости. Так, в 1971 г. руководство Китая открыто выступило с пропагандистским лозунгом: "Один ребенок - мало, два - достаточно, три - много". Началась политика по замедлению прироста населения. Более того, с приходом к власти Дэн Сяопина, убежденного в необходимости скорейшего решения демографической проблемы, в 1979 году был принят строгий закон: "Одна семья - один ребенок". Закон, который предусматривал систему штрафов за превышение установленной квоты (по данным журнала The Economist с начала 1980 года китайские власти собрали 315 миллиардов долларов штрафов за превышение квоты). Данный закон был отменен полностью лишь в 2015 году, когда руководство Китая осознало угрозу стремительного старения населения и сокращения доли рабочей силы.

Итак, к 2015 году коэффициент рождаемости в КНР опустился до 1,6. А как же обстояли дела в странах со схожим с Китаем уровнем рождаемости в 1960 году? Автор статьи сравнивает динамику коэффициента суммарной рождаемости в городской и сельской местности КНР и в 4 странах со схожими траекториями демографического перехода (Рис. 1). Разделение на город и село необходимо, поскольку реализация инициатив по сдерживанию роста рождаемости имела разный эффект в городах и деревнях. На городское население было легче влиять. Например, распространенным наказанием за превышение квоты на детей была практика увольнений с государственных предприятий. В деревнях же в основе успеха любого хозяйства лежала физическая сила, число "рук". Чем больше людей работают, тем лучше. Если в семье появлялась девочка, то это был серьезный удар, и будущее семьи оказывалось под угрозой. Так многие семьи в деревнях очень неохотно следовали букве закона.

Из рисунка 1 следует любопытный вывод: в странах с гораздо более мягкой сдерживающей рост населения политикой: Южной Корее, Таиланде, Индии и Мексике уровень рождаемости к 2010 году приблизился к тому, что был в Китае. Это наблюдение наталкивает на мысль о том, что вовсе не жесткая сдерживающая политика лежит в основе снижения прироста населения. Но что же тогда? Чжан Цзюньсен фокусирует внимание на роли экономического развития. Из рисунка 2 можно заключить, что по мере роста уровня ВВП на душу населения в развивающихся странах снижался и коэффициент рождаемости. Рисунки 1 и 2 подводят к выводу, которого придерживаются многие ученые: в Китае роль законодательных ограничений на снижение уровня рождаемости существенно переоценена. 




Рисунок 1. Коэффициент суммарной рождаемости в Китае, городское и сельское население, и в 4 выбранных для сравнения странах, 1960-2010

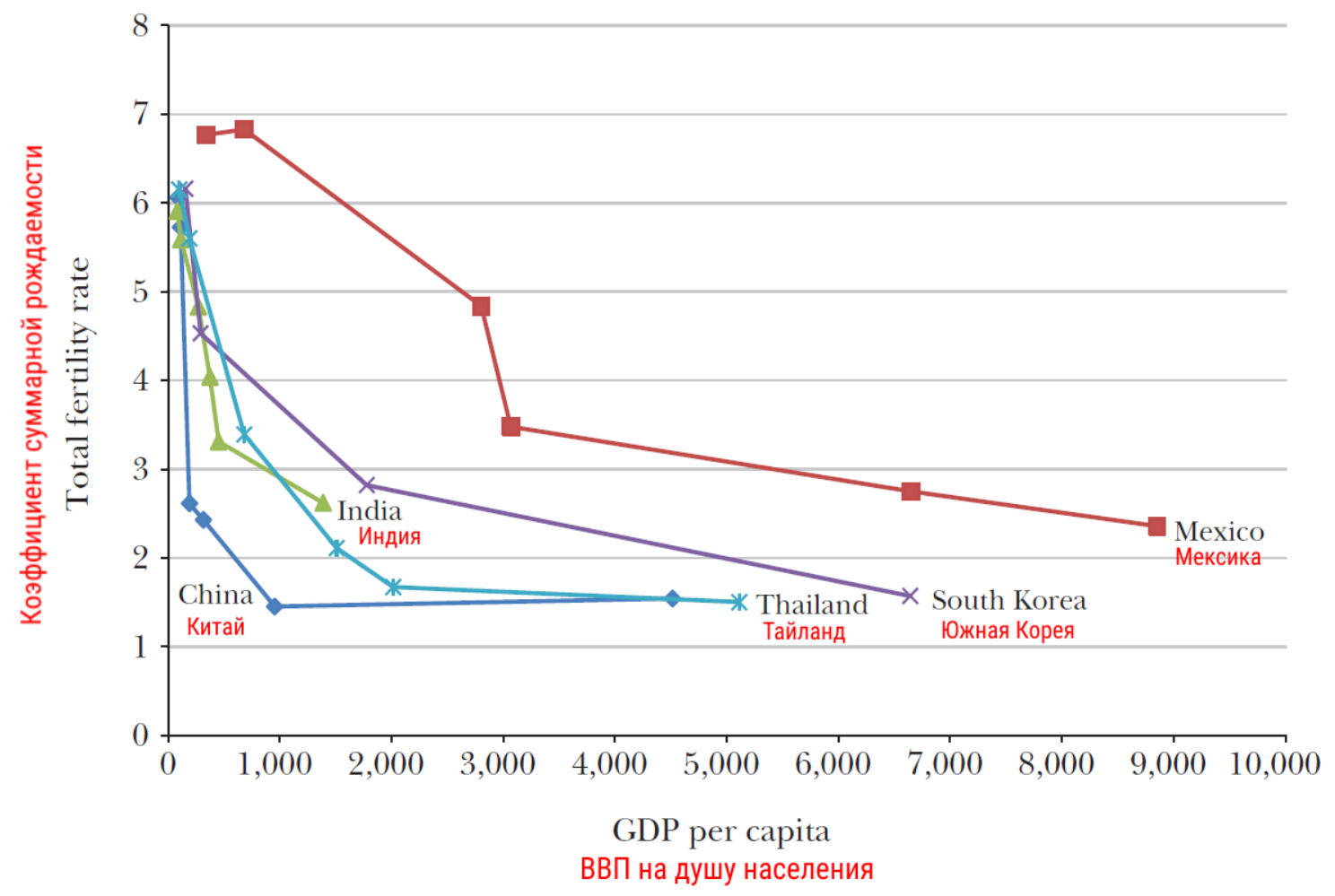

Рисунок 2. Временная динамика соотношения коэффициента суммарной рождаемости и ВВП на душу населения в Китае, городское и сельское население, и в 4 выбранных для сравнения странах, 1960-2010, с шагом в 10 лет

Оценивая последствия неукоснительного исполнения политики "Одна семья - один ребенок", автор приходит к выводу, что этот закон привел к повышению числа разводов, резко увеличил занятость мужского населения, ускорил урбанизацию и оказал (пусть и скромное) позитивное влияние на уровень образованности населения. В целом же, по 
мнению исследователя, закон, действительно, оказал влияние на уровень рождаемости в стране, но лишь в краткосрочной перспективе. В долгосрочной же перспективе наряду с другими развивающимися странами рождаемость в КНР падала в первую очередь за счет экономического развития и демографической модернизации. В то же время принятие закона имело важное социально-экономическое значение, так как оказало влияние не только на рождаемость, но также и на структуру занятости, уровень образования, а также распределение населения между городом и деревней.

\section{IS THE ASSOCIATION BETWEEN EDUCATION AND FERTILITY POSTPONEMENT CAUSAL? THE ROLE OF FAMILY BACKGROUND FACTORS}

[Tropf, F. C., \& Mandemakers, J. J. (2017). Is the Association Between Education and Fertility Postponement Causal? The Role of Family Background Factors. Demography, 54(1), 71-91. https://doi.org/10.1007/s13524-016-0531-5]

Ряд исследователей из США и Европы утверждают, что существует взаимосвязь между увеличением среднего возраста матери при рождении первого ребенка и получением более высокого уровня образования. Однако, другие ученые ставят под сомнение эту идею, предполагая, что существуют иные характеристики (социальные и / или генетические), влияющие на связь между достижениями в сфере образования и сроками рождения первого ребенка у женщин.

Авторы статьи Феликс К. Тропф и Йорнт Дж. Мандмейкерс пытаются ответить на три ключевых вопроса:

- Действительно ли образование имеет причинное воздействие на возраст при первом рождении?

- $\mathrm{B}$ какой степени отсрочка рождения первого ребенка во второй половине двадцатого века объясняется одновременным расширением образования?

- В какой степени социальный семейный фон и / или генетические факторы отвечают за наблюдаемые отношения между образованием и возрастом при первом рождении?

В качестве базы данных для анализа авторами статьи был использован реестр близнецов Великобритании. На момент написания статьи он содержал информацию примерно о 12000 человек. Авторам пришлось ограничить выборку: были удалены мужчины (так как о них информации было менее $15 \%$, что не позволило бы сделать сопоставимый анализ) и женщины моложе 40 лет при последнем наблюдении (так как это помогло избежать чрезмерного представления молодых матерей). Кроме того, было использовано два дополнительных источника Национальной статистической службы (НСС) Великобритании: информация об образовании бралась из общих обследований домашних хозяйств за период с 2000 по 2006 г., а для описания возраста матери при рождении первого ребенка были взяты оценки из НСС Великобритании.

Выполненное авторами исследование ставит под сомнение распространенный подход к объяснению различий и тенденций в определении сроков рождения детей 
различиями в уровне образования. Невелико также значение генетического наследования. Наибольшее влияние на возраст женщины при рождении первенца и его изменения оказывает социальный семейный бэкграунд.

\section{TRENDS IN THE AGE AT REPRODUCTIVE TRANSITIONS IN THE DEVELOPING WORLD: THE ROLE OF EDUCATION}

[Bongaarts, J., Mensch, B. S., \& Blanc, A. K. (2017). Trends in the age at reproductive transitions in the developing world: The role of education. Population Studies, 0(0), 1 16. https://doi.org/10.1080/00324728.2017.1291986]

Джон Бонгаартс, Барбара С. Мэнч и Эн К. Бланк, изучили взаимосвязь между продолжительностью школьного образования девочек и средним возрастом наступления "основных репродуктивных событий" - первого сексуального опыта, первого вступления в брак и первых родов. Авторы использовали данные 43 развивающихся стран Азии, Северной Африки и Африки южнее Сахары, Латинской Америки и Карибских островов, начиная с 1986 г. Главной задачей исследования было понять, в какой степени динамика среднего возраста наступления демографических событий зависит от сдвигов с образовательной структуре женского населения, а в какой степени - от изменений норм поведения.

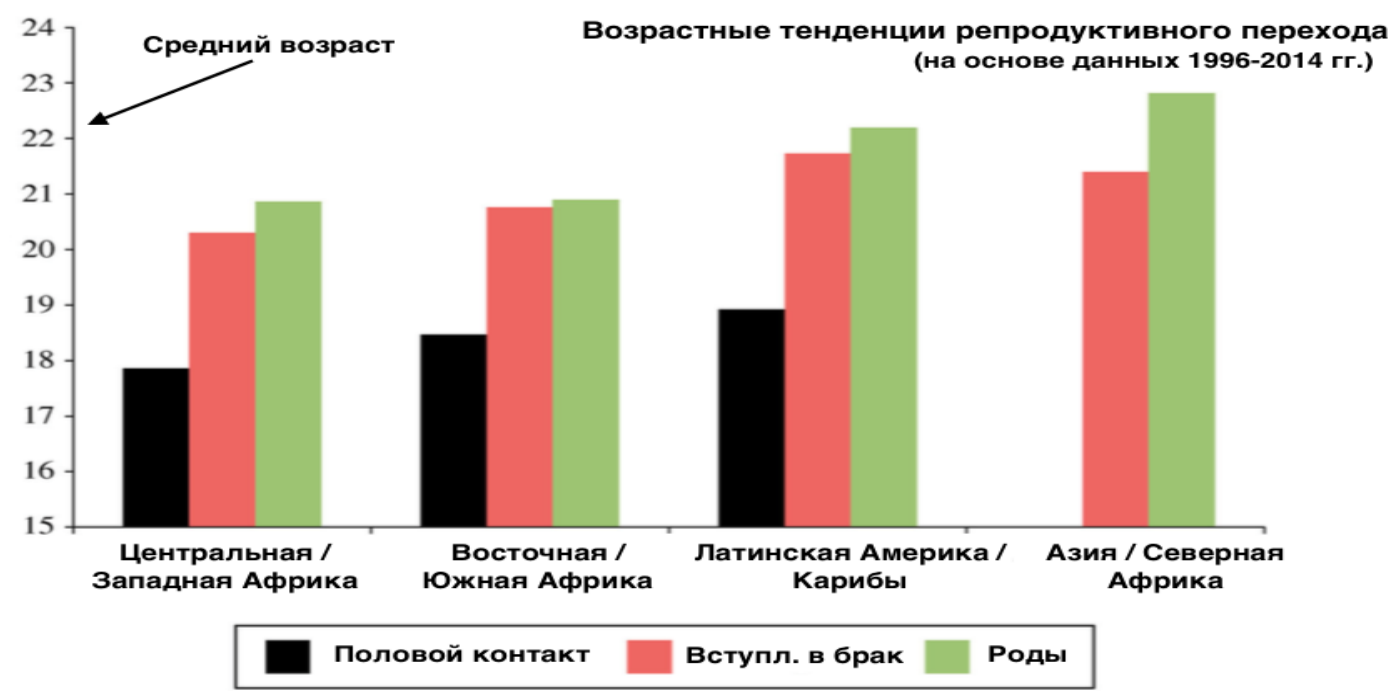

Рисунок 3. Средний возраст наступления основных репродуктивных событий в изучаемых макрорегионах

Наименьший средний возраст всех трех репродуктивных событий наблюдается в Центральной и Западной Африке (Рис. 3). Данные о первых половых контактах для Азии и Северной Африки отсутствуют, поскольку в некоторых странах данных регионов эти сведения не включались в опросы.

Так же были измерены временные промежутки между наступлением репродуктивных событий в различных их сочетаниях:

- между первым половым актом и первыми родами, 
- первым половым актом и первым браком,

- первыми родами и первым браком.

Первый показатель составил 2,5 года для Африки южнее Сахары и Латинской Америки, что говорит о распространенности добрачных половых отношений. Для Восточной и Южной Африки, Азии и Северной Африки цифра варьируется от 0,1 до 1,4 года соответственно. Авторы отмечают, что эти усредненные значения не отражают ситуацию на индивидуальном уровне, поскольку некоторые женщины, имеющие сексуальные отношения, не выходят замуж, в то время как другие, будучи замужем, никогда не имели детей.

Примечательно, что во всех странах, за исключением одной, возраст первого вступления в брак был выше возраста первого полового контакта или равнялся ему (Рис. 4).

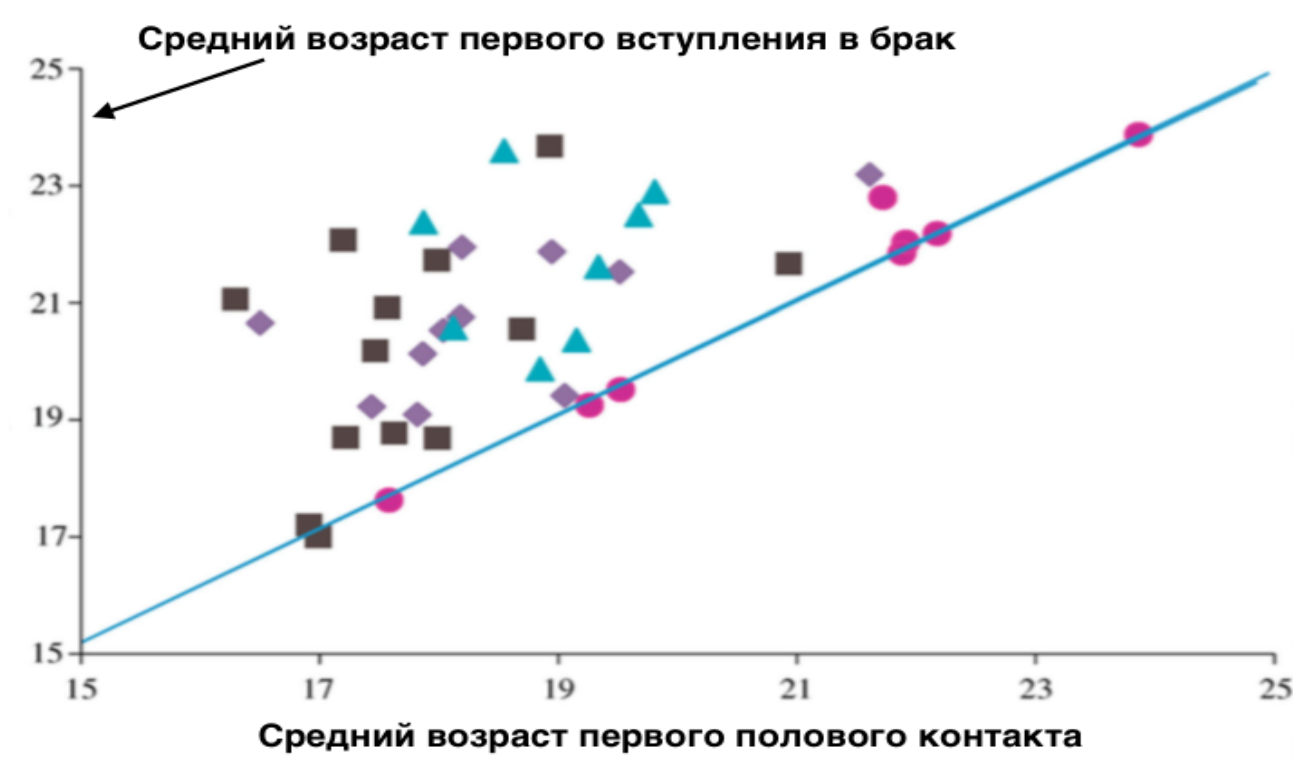

\begin{tabular}{|c|c|c|c|}
\hline $\begin{array}{c}\text { Центральная / } \\
\text { Западная } \\
\text { Африка }\end{array}$ & $\begin{array}{c}\text { Восточная / } \\
\text { Южная Африка }\end{array}$ & $\begin{array}{c}\text { Латинская } \\
\text { Америка / Карибы }\end{array}$ & $\begin{array}{c}\text { Азия / } \\
\text { Северная } \\
\text { Африка }\end{array}$ \\
\hline
\end{tabular}

\section{Рисунок 4. Соотношение возраста первого полового контакта и вступления в первый брак}

Средний возраст первых родов в большинстве случаев превышает возраст первого вступления в брак, хотя есть и исключения, которые характерны для стран, где распространено добрачное деторождение (Рис. 5). 


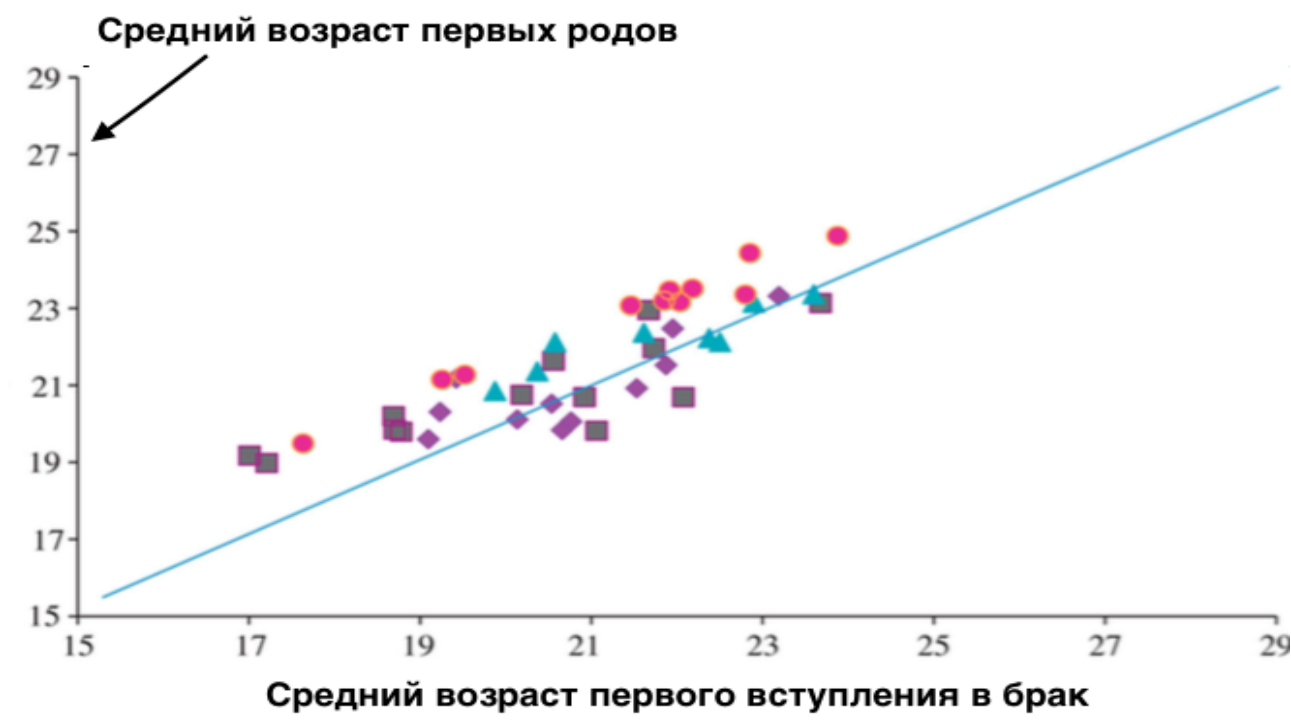

\begin{tabular}{|c|c|c|c|c|c|}
\hline [ & $\begin{array}{l}\text { Центральная / } \\
\text { Западная } \\
\text { Африка }\end{array}$ & $\begin{array}{c}\text { Восточная / } \\
\text { Южная Африка }\end{array}$ & A $\begin{array}{c}\text { Латинская } \\
\text { Америка / Карибы }\end{array}$ & $\bullet$ & $\begin{array}{c}\text { Азия / } \\
\text { Северная } \\
\text { Африка }\end{array}$ \\
\hline
\end{tabular}

\section{Рисунок 5. Соотношение среднего возраста вступления в первый брак и рождения первого ребенка}

Во всех исследуемых регионах наблюдались значительные позитивные изменения в распространении образования среди женщин на момент их первых родов. К 2010 г. во всех регионах, кроме Центральной и Западной Африки, где 39\% женщин все еще оставались без школьного образования, более 4 женщин из 5 получили образование. В Северной Африке, Латинской Америке и Карибских островах почти 2/3 женщин получили среднее образование, для сравнения в 1990-х - менее половины.

Как и следовало ожидать, повышение уровня образования прямо пропорционально повышению среднего возраста наступления всех трех репродуктивных событий. Также выяснилось, что наличие среднего образования играет ключевую роль, т.к. различие в средневозрастных показателях между женщинами, получившими среднее образование и окончившими лишь начальную ступень, гораздо выше, чем между получившими начальное образование и не получившими никакого.

Любопытно, что позитивные тенденции для всех уровней образования вместе были сильнее, чем для какого-либо уровня в отдельности, поскольку средний уровень образования в целом повышается и больший вес обретают более образованные группы населения.

Также авторы исследования обратили внимание на наличие двух различных компонентов общего возрастного тренда:

- Первый - "композиционный эффект" - относится к повышению качества образования, благодаря которому растет численность более образованных и уменьшается численность менее образованных группы, а также возрастает средний темп увеличения возраста наступления того или иного репродуктивного события. 
- Второй - "уровневый эффект" - относится к средним показателям для определенного уровня образования, который варьируется в зависимости от региона и имеет восходящий характер в Африке южнее Сахары, Азии и Северной Африке, и нисходящий - в Латинской Америке и на Карибских островах.

Чтобы количественно оценить роль этих двух факторов, ученые применили метод декомпозиции (Рис. 6). В целом относительно всех трех событий композиционный эффект оказался сильнее и позитивнее "уровневого", чье направление и показатели существенно менялись. в зависимости от региона и типа события.
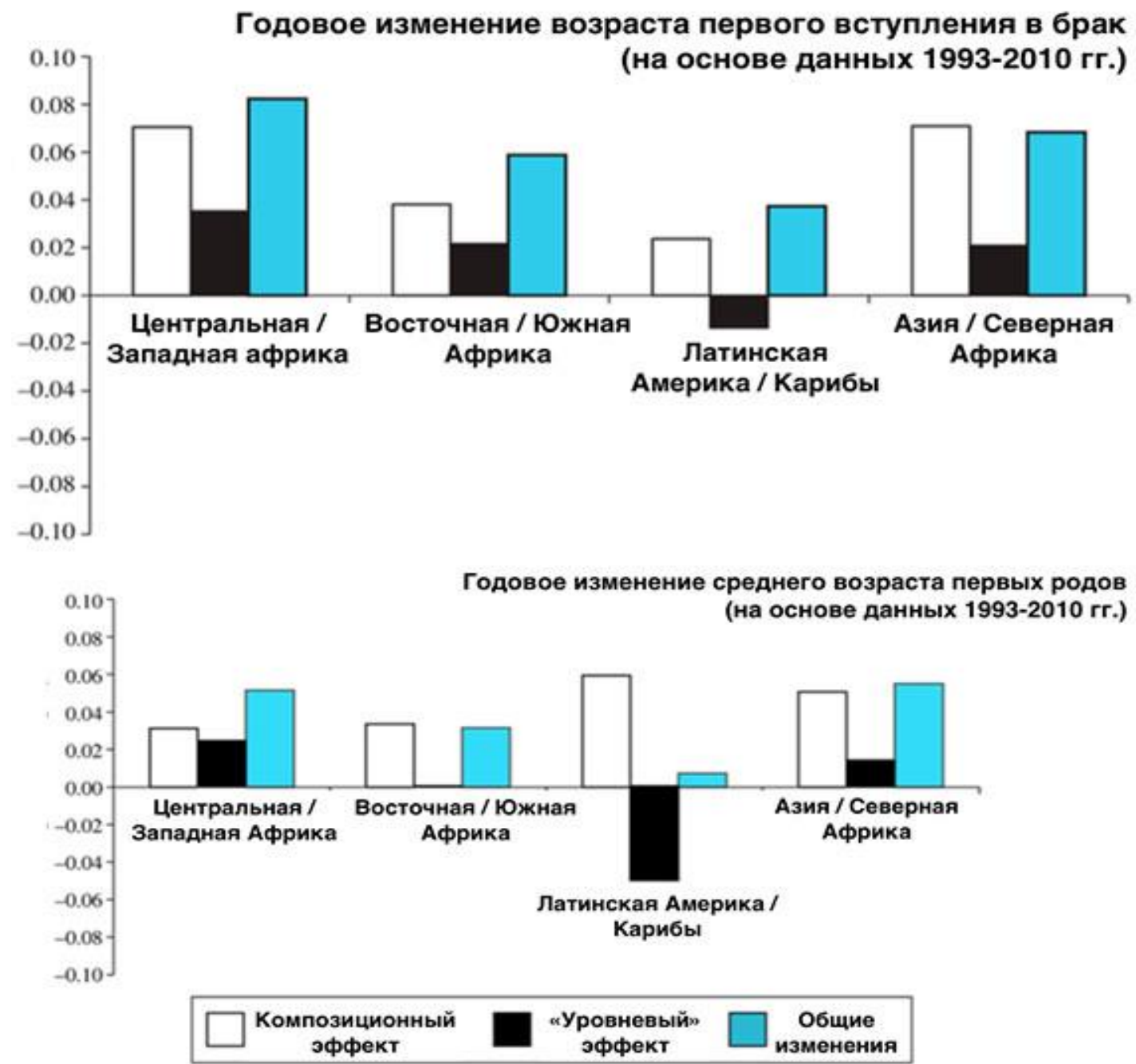

Рисунок 6. Декомпозиция среднегодовых изменений среднего возраста наступления репродуктивных событий на структурную и трендовую компоненты: А) - возраста вступления в первый брак; Б) возраста первых родов

Авторы отмечают, что единого определяющего фактора возрастной динамики найдено не было - в зависимости от региона им является либо распределение женского населения по уровням образования, либо репродуктивное поведение, установившееся определенной в группе. Кроме того, необходимо учитывать прочие политические, экономические и культурные факторы, влияющие на установки репродуктивного поведения. 


\section{INFLUENCE OF HETEROGAMY BY RELIGION ON RISK OF MARITAL DISSOLUTION: A COHORT STUDY OF 20,000 COUPLES}

[Wright, D. M., Rosato, M., \& O'Reilly, D. (2017). Influence of Heterogamy by Religion on Risk of Marital Dissolution: A Cohort Study of 20,000 Couples. European Journal of Population, 33(1), 87-107. https://doi.org/10.1007/s10680-016-9398-9]

Дэвид М. Райт, Майкл Розато и Дермот О'Рейли изучили, как принадлежность к различным религиозным конфессиям влияет на риск расторжения брака. Ученые вводят понятие "гетерогенного эффекта", который заключается в увеличении риска распада брака в зависимости от силы культурных, социально-экономических, образовательных и особенно конфессиональных различий внутри пары.

За основу были взяты данные североирландских панельных обследований, также использовались данные североирландских переписей населения 2001 и 2011 гг. В итоговой модели была использована информация о 19791 супружеской паре с возрастом супругов от 16 до 74 лет в 2001 г., для которых была указана религиозная принадлежность обоих партнеров.

Влияние различия в ценностных установках и внешнего давления на расторжение религиозно-гетерогенных браков изучается нечасто, именно поэтому исследование было проведено на основе данных из Северной Ирландии, где эта проблема актуальна, поскольку существует глубокий разрыв между протестантами и католиками.

Авторы задают два главных вопроса:

- Повышает ли религиозная гетерогамия риск распада брака в Северной Ирландии?

- Возрастает ли риск распада протестантско-католических браков пропорционально уровню сегрегации населения по религиозному принципу?

Несколько статистических моделей описывают весьма сложные взаимосвязи религиозного фактора с социально-экономическими, возрастными и образовательными особенностями.

Как и ожидалось, католико-протестантские браки были подвержены более высокому риску распада, чем гомогенные браки. Похожие результаты ранее были получены в Нидерландах. Любопытно, что конфессиональные различия оказывают более значимый эффект, нежели у смешанных по этнолингвистическому признаку шведско-финских пар в Финляндии. Независимо от исторической давности межгруппового конфликта (например, война за независимость Северной Ирландии во второй половине $\mathrm{XX}$ в.), он оказывает устойчивое негативное влияние на развитие брака, выходя за рамки исключительно этнических различий. Однако доля таких более подверженных риску католикопротестантских браков относительно браков гомогенных не слишком велика.

Авторам не удалось найти подтверждение гипотезе о влиянии религиозной сегрегации населения и концентрации представителей определенной общины в области проживания смешанной пары на вероятность расторжения брака. Это удивительно, потому что сегрегация по признаку "католик/протестант" до сих пор является характерной чертой 
североирландского социологического ландшафта. Объяснением может служить тот факт, что религиозная гетерогамия, в первую очередь, влияет скорее на установки и ожидания внутри пары, нежели на все сообщество. Также это может быть обусловлено нерепрезентативностью использованных данных, которые не отражают реального положения дел относительно окружения, в котором пара проводит большую часть времени.

\section{WHO IN EUROPE WORKS B ELDERLY WOMEN LIVING ALONE IN SPAIN: THE IMPORTANCE OF HAVING CHILDREN}

[Reher, D., \& Requena, M. (2017). Elderly women living alone in Spain: the importance of having children. European Journal of Ageing, 1-12. https://doi.org/10.1007/s10433017-0415-6]

В последние десятилетия все большее количество пожилых людей (традиционно, к этой группе принято относить людей старше 65 лет) из развитых стран живут в одиночестве это наблюдается даже в обществах, где большое значение предается сохранению и поддержанию семейных ценностей. Помимо того, в развитых странах наблюдается снижение рождаемости, что становится характерным процессом даже для обществ с традиционно прочными семейными системами (страны Восточной и Южной Европы). Эти тренды указывают на одновременное развитие двух процессов: 1) увеличение числа одиноко живущих людей; 2) увеличение числа бездетных людей.

Сравнительные исследования показали, что бездетные пожилые люди чаще проживают одни, по сравнению с пожилыми людьми, которые имеют детей. В своей статье Давид Реэр и Мигель Рекена подчеркивают, что данная закономерность требует тщательного рассмотрения и анализа, поскольку любая взаимосвязь, касающаяся репродуктивных характеристик отдельно взятого общества, позволяет спрогнозировать будущие тенденции, основанные на текущих показателях. На основе микроданных, полученных в ходе переписи населения Испании в 2011 году, исследователи при помощи логистической регрессии оценили влияние рождаемости на фактор одинокого проживания женщин разного брачного состояния. Результаты модели представлены как соотношение шансов (OR - Odd ratios): у имеющих одного ребенка женщин даже при различных семейных положениях, шанс одинокого проживания в пожилом возрасте значительно ниже, чем у бездетных. Шанс одинокого проживания в пожилом возрасте снижается по мере увеличения количества детей у женщины (Рис. 7). Таким образом, наличие потомства выступает в качестве некоего буфера против одиночества в старости.

Исследователи также подчеркивают, что в будущем ожидается нехватка семейных ресурсов, доступных для пожилых женщин. В обществах, где модели рождаемости, характерные для второй половины двадцатого века, породили большое количество малочисленных семей без детей или с одним ребенком, все большее число бездетных пожилых женщин столкнутся с отсутствием или нехваткой родственников и будут вынуждены жить одни. При этом традиционно в таких странах, как Испания, относительно низко развитая система социальной поддержки населения, в частности пожилых людей, со стороны государственных институтов обычно компенсируется как раз (хотя бы частично) за счет активной помощи внутри семей. Именно Испания, по мнению исследователей, 
является ярким примером общества, где поддержание уровня жизни пожилых людей во многом опирается на семейные узы. Тем не менее, в течение следующих двух десятилетий число бездетных женщин в Испании увеличится в 1,38 раза (по сравнению с 2011 годом) и к 2031 году количество бездетных пожилых женщин достигнет 1,031 миллиона. Одновременно количество бездетных пожилых женщин, которые живут одни, увеличится с 1,3 миллиона в 2011 году до 1,9 миллиона в 2031 году. Авторы статьи отмечают, что эта революция в одиноком проживании будет частично смягчена тем, что в Испании в ближайшем будущем также увеличится доля пожилых женщин, живущих с партнером, изза продолжающегося увеличения уровня продолжительности жизни мужчин.

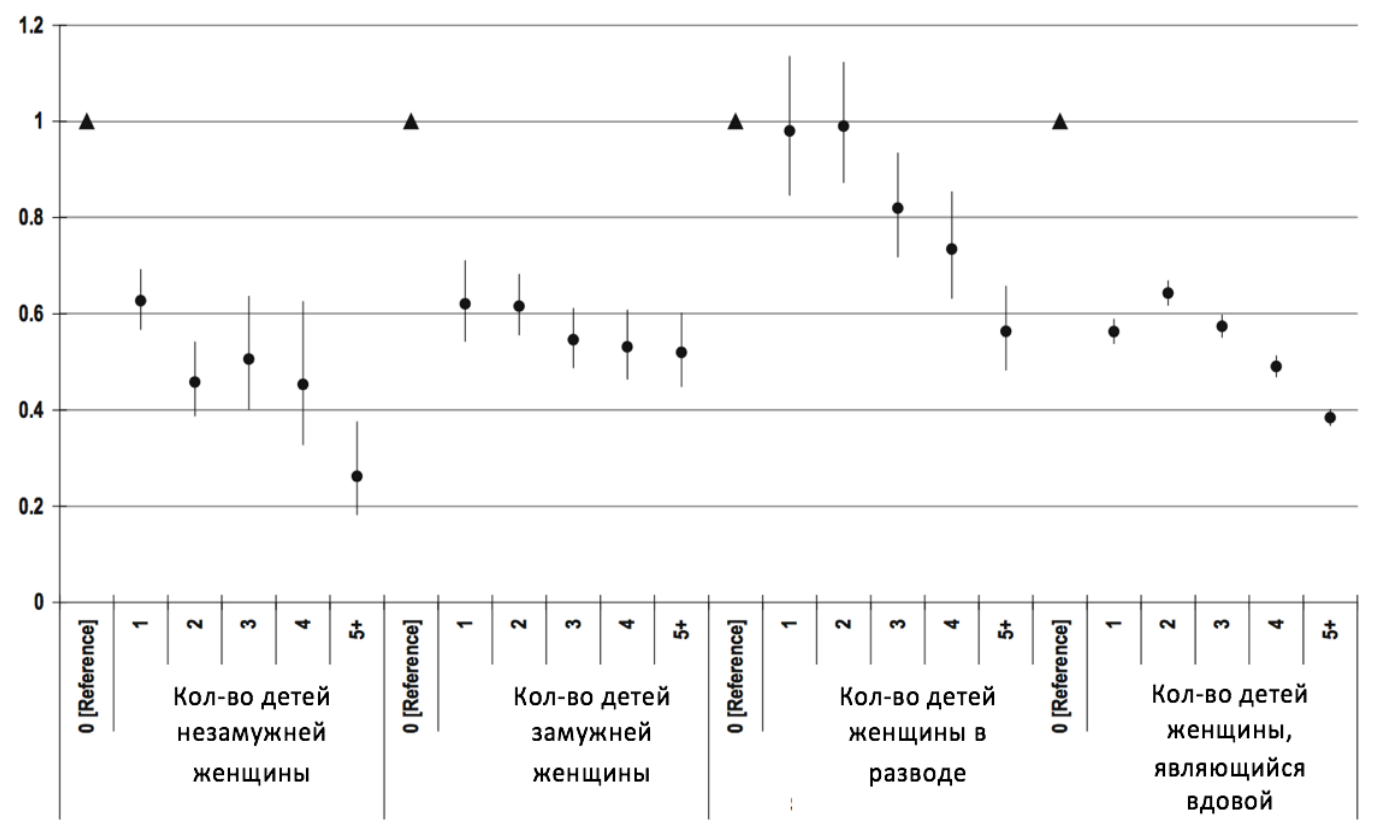

Рисунок 7. Риски одинокого проживания в зависимости от семейного статуса женщины и количества детей

\section{PARENTS' TIME WITH A PARTNER IN A CROSS-NATIONAL CONTEXT: A COMPARISON OF THE UNITED STATES, SPAIN, AND FRANCE}

[Garcia-Roman, J., Flood, S., \& Genadek, K. (2017). Parents' time with a partner in a cross-national context: A comparison of the United States, Spain, and France. Demographic Research, 36(4), 111-144. https://doi.org/10.4054/DemRes.2017.36.4]

Одинаковое ли время проводят вместе супружеские пары из разных стран мира? Хуан Гарсия-Роман, Сара М. Флад и Кати Р. Генадек изучили как культурные нормы и социальные условия влияют на продолжительность проведенного вместе времени у супружеских пар из США, Франции и Испании.

Авторы предполагают, что социальная и политическая обстановка влияет на общее время, проведенное с партнером. Так, например, США, Франция и Испания имеют 
различную систему социальной поддержки. Это проявляется в таких сферах, как занятость женщин, социальная помощь по уходу за ребенком, стандарты воспитания детей. Экономическая модель Соединенных Штатов характеризуется низкой степенью социальной защиты и скромной ролью государства в сфере услуг, а семейные обязанности не обозначены строго. Во Франции оказание существенной поддержки семье входит в обязанности государства, которое стремится к сохранению традиционных форм семьи. В Испании, где семья считается одним из ключевых факторов благосостояния, традиционные гендерные нормы главенствовали до начала 21 века. Более того, в Испании матери отводится роль главного воспитателя ребенка. В изученных странах наиболее высокий процент занятости матерей - во Франции (72\%), а наименьший - в Испании (57\%). Тем не менее, американские матери проводят времени на работе больше, чем француженки или испанки. Авторы связывают такое явление с государственной политикой этих стран, которая дает возможность матерям работать или, наоборот, вынуждает проводить больше времени с детьми. Например, во Франции широко распространены государственные детские сады, что объясняет большую долю французских женщин на рынке труда. В Испании из-за недостаточной государственной поддержки семьи матери работают меньше, так как воспитание ребенка осуществляется в семье.

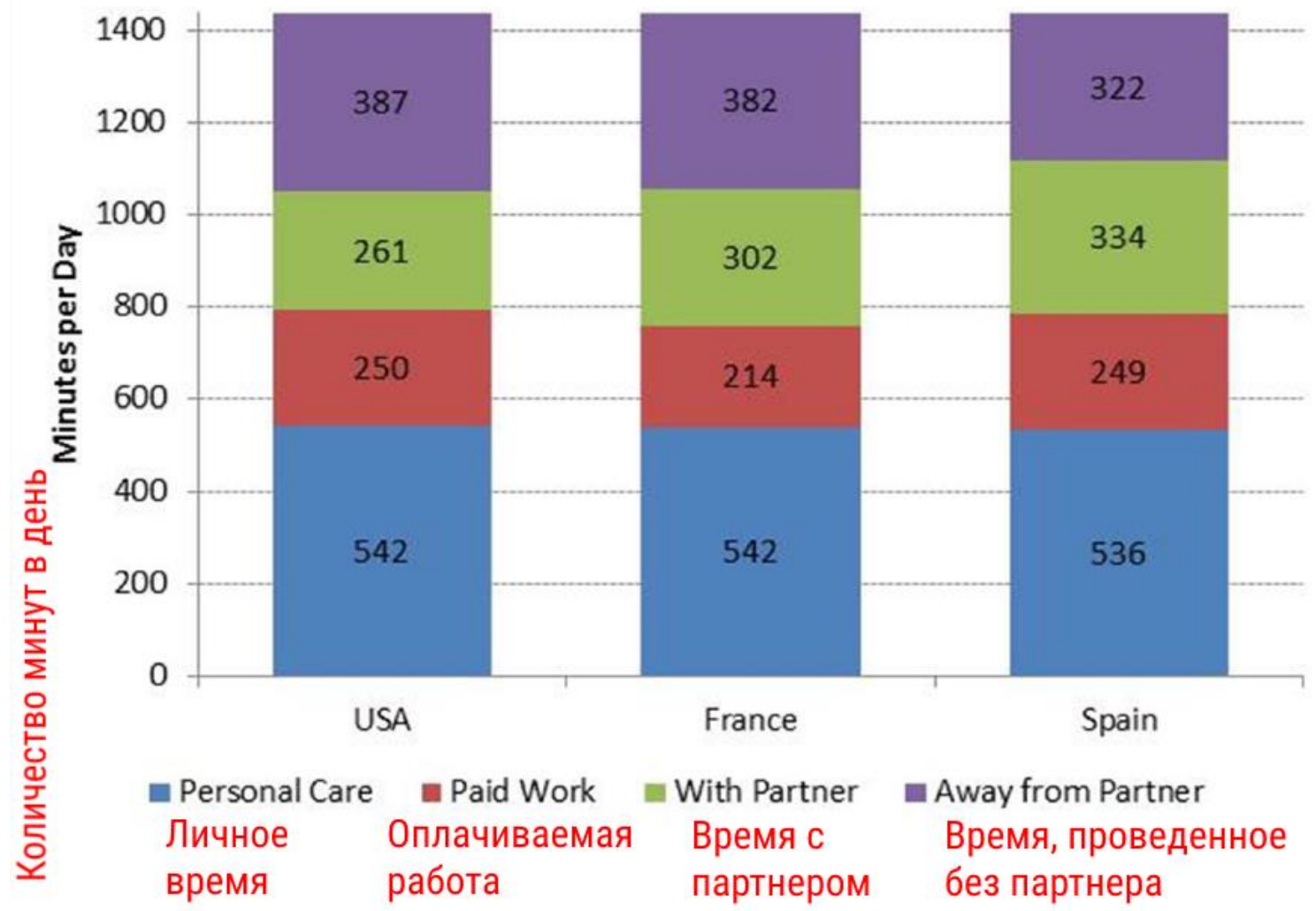

\section{Рисунок 8. Среднее количество времени, проведенного в течение суток за различными занятиями}

Согласно исследованию, родители в США работают дольше всего (250 минут в день), а времени с партнером проводят меньше других (261 минута). Французские родители работают на 35 минут в день меньше американцев, а времени с партнером проводят на 40 минут больше. Испанцы же работают почти столько же, сколько родители в США, но с 
партнером проводят на 73 минуты больше, чем американские родители (Рис. 8). Все эти различия оказываются статистически значимыми.

В выходные дни люди, как правило, имеют возможность проводить больше времени с семьей и супругом. Однако даже в такие дни время, проведенное как наедине с партнером, так и в кругу семьи, различается в зависимости от страны (Рис. 9). По выходным время, проведенное с семьей, у испанцев особенно велико, что приводит к еще большему отрыву Испании от США и Франции.

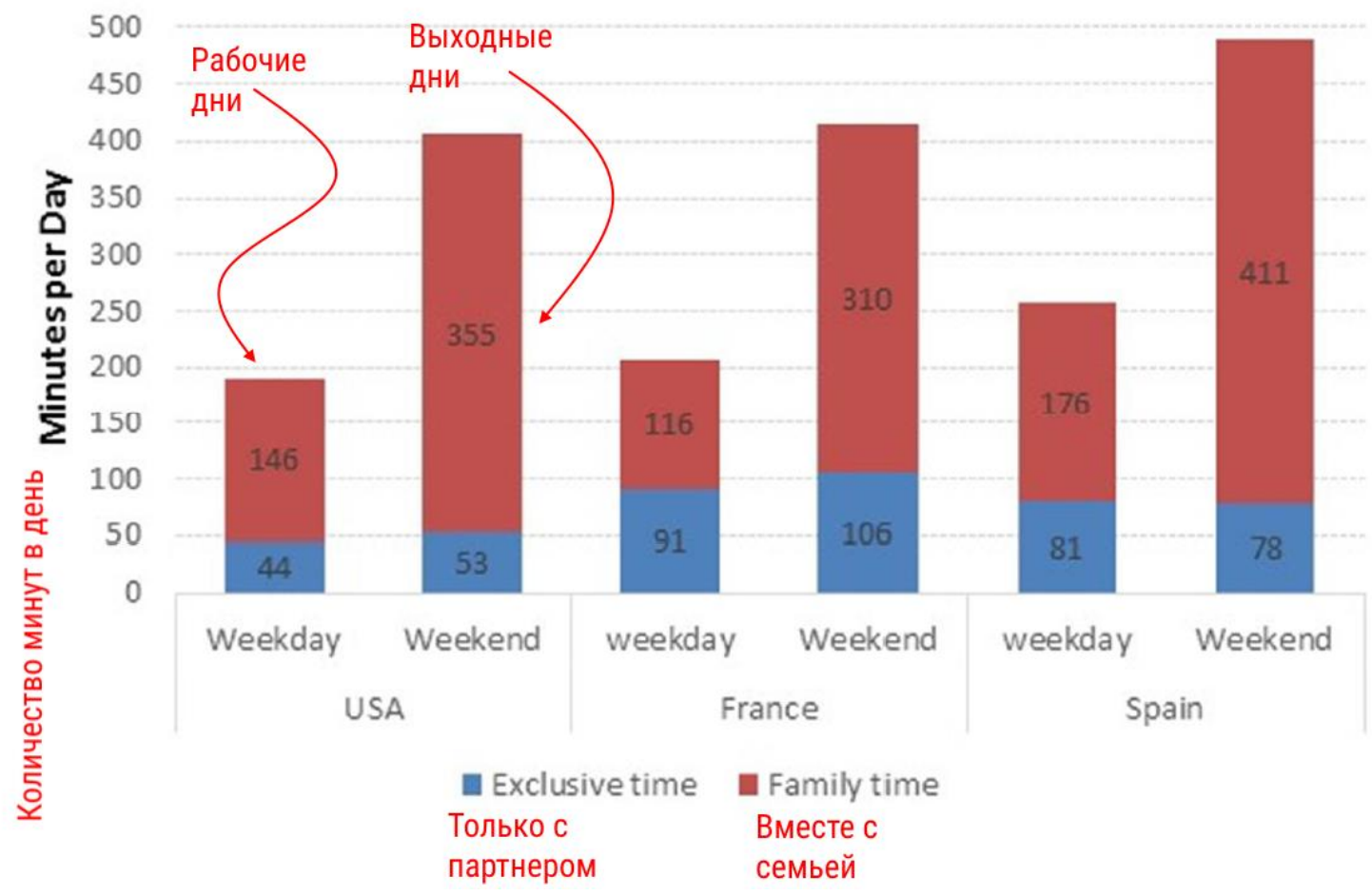

Рисунок 9. Среднее время, проведенное с партнером и с остальными членами семьи, в будни и на выходных

Из исследования следует, что супружеские пары в среднем проводят время одинаково: выполняют работу по дому, совместно питаются, путешествуют, смотрят телевизор и ухаживают за детьми. Вместе с тем, существуют качественные различия во времени, которое испанцы, американцы и французы тратят на эти занятия. Например, в США супруги тратят на совместный прием пищи в среднем 41 минуту в день, что практически в 2 раза меньше того времени, которое этому занятию отводят французы и испанцы (около 80 минут). Увидеть другие интересные особенности распределения совместного времени супругов в изучаемых странах позволяют хронограммы (Рис. 10).

На количество времени, которое партнеры проводят вместе, влияет множество факторов. Несмотря на то, что занятость на работе оказывает большое влияние на время, проведенное совместно с партнером, существуют и другие, не менее важные обстоятельства, которые это время ограничивают. К таким факторам относятся устоявшиеся в странах нормы культурной жизни (например, в области питания), традиционные представления о семье, а также политика правительств этих стран в области отцовства и материнства. 


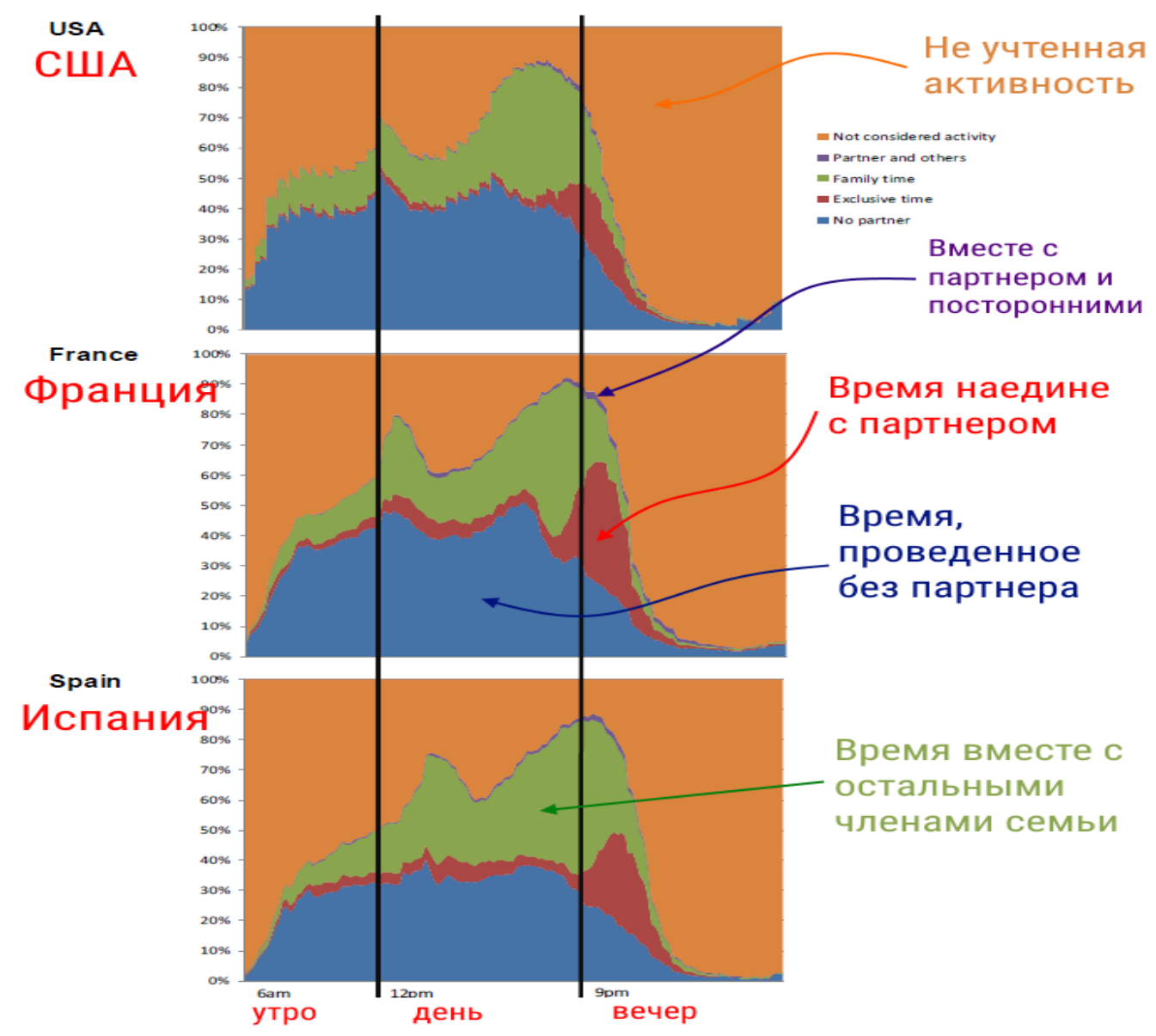

Рисунок 10. Хронограммы распределения времени партнеров

\section{EYOND THE STATE PENSION AGE AND UNDER WHICH CONDITIONS? RESULTS FROM SHARE}

[Wahrendorf, M., Akinwale, B., Landy, R., Matthews, K., \& Blane, D. (2017). Who in Europe Works beyond the State Pension Age and under which Conditions? Results from SHARE. Journal of Population Ageing, 10(3), 269-285. https://doi.org/10.1007/s12062016-9160-4]

Беспрецедентные темпы старения населения требуют от правительств европейских стран активных мер по адаптации социально-экономической политики. Так, в частности, активно обсуждаются и внедряются меры по расширению присутствия пожилых работников на рынке труда и увеличению пенсионного возраста. При этом существует ряд исследований, которые выявили ключевые факторы, предопределяющие более ранний выход работника на пенсию. Однако относительно мало известно о людях, которые продолжают работать и после достижения пенсионного возраста, об условиях их работы и занятости.

В связи с этим группа немецких и британских исследователей (Мортен Варендорф, Бола Акинвале, Ребекка Лэнди, Кэти Мэтьюз и Дэвид Блейн), используя результаты социологического Исследования здоровья, старения и выхода на пенсию в Европе (SHARE - Survey of Health, Ageing and Retirement in Europe), решили описать условия труда пожилых 
работников, находящихся в возрасте старше 65 лет. Кроме того, было проведено сравнение условий труда пожилых людей, которые продолжили работать после достижения пенсионного возраста, с трудовыми условиями (на последнем рабочем месте) тех, кто все же ушел на пенсию. Помимо социально-демографических факторов (таких как, например, наличие брачного партнера или уровень материального состояния) и здоровья (как физического, так и психического), в работе уделяется особое внимание условиям занятости, а также психосоциальным стресс-факторам на работе (измеряются в терминах двух теоретических моделей рабочего напряжения - модели контроля спроса и модели дисбаланса усилий и вознаграждения).

По мнению исследователей, результаты их анализа могут оказаться крайне полезными при разработке мер по увеличению срока трудовой жизни населения, поскольку позволяют определить факторы, влияющие на пенсионное поведение. Авторы выявили следующие закономерности:

- К Каждый третий человек, работающий в возрасте от 65 до 80 лет, либо работает на себя, то есть является самозанятым, либо обладает высокой профессиональной квалификацией и занимает выгодную должность. На неработающих пожилых людей приходится значительно меньшая доля самозанятых или квалифицированных специалистов. Таким образом, исходное предположение авторов нашло подтверждение на эмпирических данных: продолжать работать склонны более квалифицированные или самозанятые люди. Возможно, у самозанятых работников меньше шансов получить щедрую пенсию, что приводит к увеличению стимулов (и необходимости) к продолжению трудовой деятельности, а высококвалифицированные специалисты, предполагают исследователи, получают удовольствие от работы и продолжают трудиться, несмотря на то, что они могут рассчитывать на достаточно щедрые пенсионные выплаты.

- Данное предположение подтверждается вторым результатом анализа, который показывает, что психосоциальные условия труда обычно лучше у тех, кто остается работать и после достижения пенсионного возраста.

- Говоря о здоровье, исследователи отмечают, что физическое и психическое состояние пожилых людей, которые продолжили работать, как правило, лучше, чем у тех, кто все же вышел на пенсию (Рис. 11).

Таким образом, результаты исследования говорят о том, что продолжительная трудовая жизнь человека часто сопряжена с благоприятными условиями занятости и психосоциальными обстоятельствами. Кроме того, люди, работающие в возрасте старше 65 лет, скорее всего, достаточно здоровы и находятся в относительно хорошем психическом и физическом состоянии. С другой стороны, не каждый человек обладает данными трудовыми условиями, а значит, не каждый сможет и будет продолжать работать после достижения пенсионного возраста. Социально-экономическая политика, направленная на увеличение государственного пенсионного возраста, может оказывать давление на определенные группы населения. 


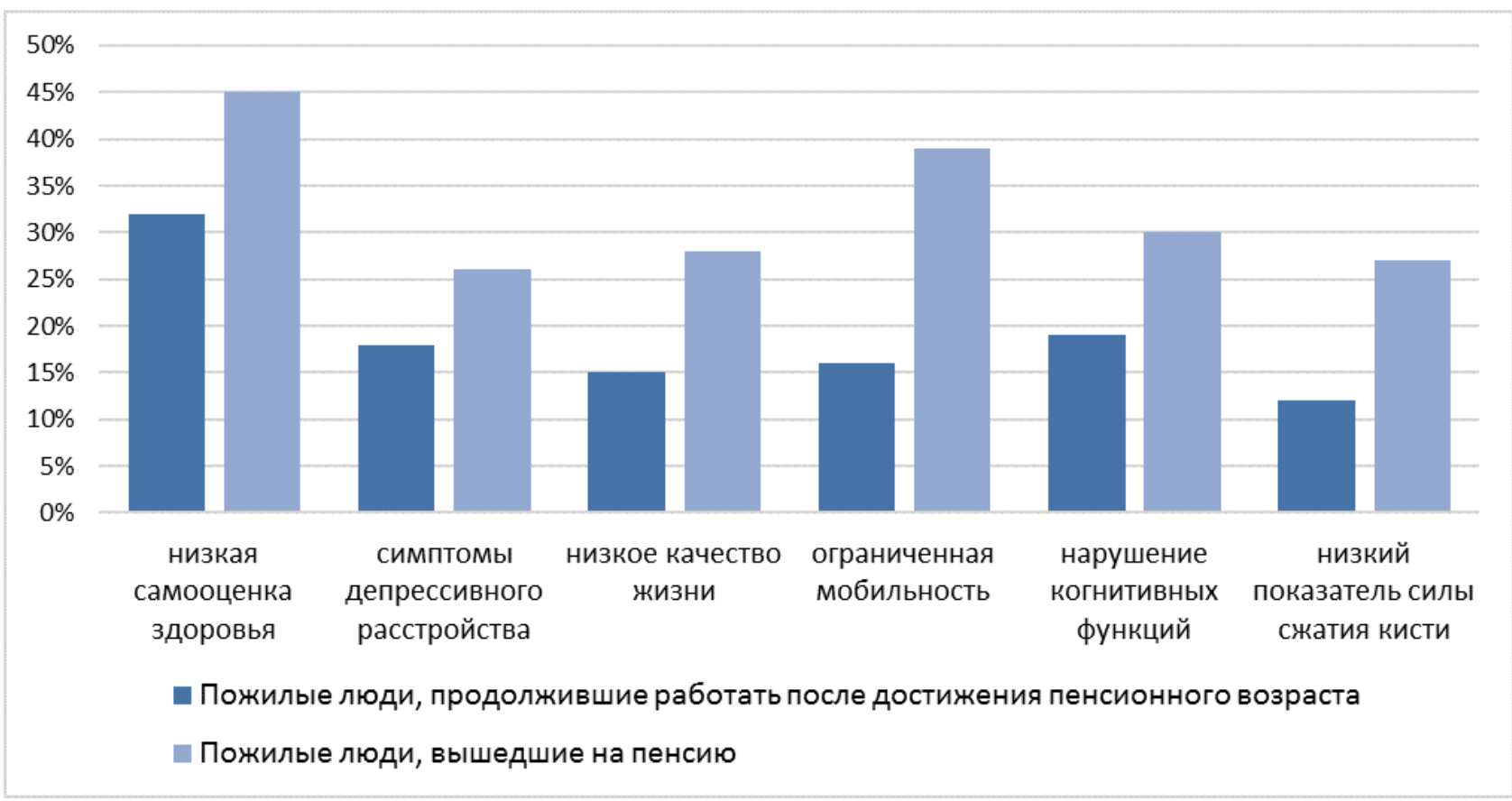

Рисунок 11. Показатели уровня здоровья мужчин и женщин пожилого возраста (от 65 до 80 лет) в зависимости от их положения на рынке труда, в процентах

\section{THE INTERREGIONAL MIGRATION OF HUMAN CAPITAL AND ITS REGIONAL CONSEQUENCES: A REVIEW}

[Faggian, A., Rajbhandari, I., \& Dotzel, K. R. (2017). The interregional migration of human capital and its regional consequences: a review. Regional Studies, 51(1), 128143. https://doi.org/10.1080/00343404.2016.1263388]

Вследствие произошедшей в конце 1980-х гг. глобализации рынка рабочей силы трудовая миграция имеет значительные последствия как для отдающих, так и для принимающих регионов. Статья Алессандры Фаджиан, Иша Ражбандари и Катрин Дотцел представляет собой обзор научных трудов, посвященных теме миграции высококвалифицированных работников, людей с высоким человеческим капиталом.

Рассматривая позитивные последствия для принимающих регионов, авторы отмечают важную роль мигрантов в инновационном развитии, а также в научном прогрессе. Высококвалифицированные мигранты усиливают человеческий капитал региона прибытия, делают большой вклад в научное и технологическое развитие, что способствует экономическому росту. Например, есть свидетельства того, что доля мигрантов среди выпускников колледжей США положительно влияет на развитие инноваций: увеличение на $1 \%$ количества иммигрантов, закончивших американские высшие учебные заведения, увеличивает на $6 \%$ количество патентов.

Приток высококвалифицированных мигрантов отражается и на зарплатах в регионе. С одной стороны, такие мигранты увеличивают производительность рабочей силы, тем самым вызывая и увеличение зарплат. $\mathrm{C}$ другой стороны, обилие высококвалифицированных мигрантов увеличивает соответствующее предложение на 
рынке труда, тем самым изменяя в меньшую сторону зарплату, предлагаемую работникам. При этом большое количество высококвалифицированных кадров в регионе может вызвать недостаток менее квалифицированной рабочей силы, что приводит к диспропорциональному росту оплаты их труда на фоне соседних регионов.

Мигранты с высокой квалификацией несут выгоду для фирм, которые их нанимают. Используя свои профессиональные связи за пределами региона, высококвалифицированные мигранты вносят ощутимый вклад в производительность труда в регионе. Более того, увеличивая этническое и культурное разнообразие, такие работники увеличивают привлекательность как региона, так и отдельного предприятия для новых высококлассных специалистов.

Однако для принимающей стороны существуют и негативные последствия. Вопервых, отдельные группы населения могут упустить некоторые экономические выгоды изза чрезмерного притока высококвалифицированных мигрантов. Авторы приводят в пример изменение цены на товары с неэластичным спросом, например, недвижимость. Во-вторых, есть основания полагать, что для экономического роста удовлетворенность работников играет большую роль, чем количество высококвалифицированной рабочей силы. Внося разнообразие в этнический состав региона, миграция может привести к росту недоверия и ухудшению коммуникации между работниками, что негативно отразится на производительности.

Говоря о последствиях для регионов выбытия, авторы статьи подчеркивают, что количество исследований на эту тему сильно ограничено. Это связано с тем, что эмигранты есть в каждом регионе, а список регионов, привлекательных для высококвалифицированных мигрантов, не бесконечен.

Анализируя позитивные последствия для региона выбытия, авторы отмечают, что удачный опыт эмиграции может оказать на него положительное влияние, ведь успешные эмигранты нередко становятся примером, побуждая других инвестировать в свое образование, что увеличивает человеческий капитал и способствует экономическому росту. Кроме того, ученые указывают на заметное увеличение перспектив развития, а также на рост заработной платы в регионах, которые традиционно были "поставщиками" мигрантов. Например, ожидается, что отток мигрантов в сельскую местность в Китае увеличит инвестиции в сельское хозяйство. Вдобавок, возвращение высококлассных специалистов повышает человеческий капитал, что создает позитивные внешние факторы для развития экономики в регионе.

Два главных негативных последствия эмиграции для регионов - снижение человеческого капитала как следствие утечки мозгов, а также депопуляция. Иммигранты в США имеют образование более высокого уровня, чем среднестатистический гражданин в регионе, откуда они уезжают. Более того, высококлассные специалисты обладают наибольшей мобильностью, и это упрощает их эмиграцию из исходного региона. 


\section{DOES RELIGION MATTER TO CORRUPTION? EVIDENCE FROM CHINA}

[Xu, X., Li, Y., Liu, X., \& Gan, W. (2017). Does religion matter to corruption? Evidence from China. China Economic Review, 42(Supplement C), 34-49. https://doi.org/10.1016/j.chieco.2016.11.005]

С началом экономических реформ конца 1970-х гг. в Китае интенсивный рост ВВП сопровождался не менее быстрым распространением коррупции - серьезность этой проблемы официально признана Коммунистической партией Китая.

Исследователи посвятили свою работу изучению взаимосвязи между рентоориентированным поведением властей и религией, отмечая на недостаточное внимание ученых к роли этого фактора при анализе распространения коррупции. В связи с отказом от обязательного государственного атеизма за последние 30 лет роль религии в общественной жизни в Китае многократно возросла. Недавние исследования показывают, что люди, придерживающиеся религиозных убеждений, меньше нарушают закон и испытывают больше доверия к рыночным институтам. Таким образом, религия может служить этическим ограничителем социально неверного поведения и способствовать большему контролю элит со стороны общества.

Исходя из данного предположения, авторы исследования выдвинули две гипотезы:

1. Между религиозностью и коррупцией существует отрицательная зависимость.

В то же время борьба с коррупцией напрямую связана с эффективностью законодательства и правоприменения. В условиях слабых правовых институтов в Китае религия может выступать неформальным фактором сдерживания коррупции. Однако выступают ли религиозные и правовые нормы заменителями друг друга или оказывают совместный антикоррупционный эффект?

Из этого вопроса вытекает вторая гипотеза:

2. Отрицательная зависимость между религиозностью и коррупцией ослабевает в провинциях с относительными сильными правовыми институтами

Исследователи анализировали данные за 1998-2009 гг. на территории 22 провинций, 4 автономных регионов и 4 муниципалитетов (не включая Тибет, Гонконг, Макао и Тайвань). Для измерения коррупции использованы два показателя: число зарегистрированных случаев коррупции на 10.000 человек в данной провинции за год (Corruption Frequency) и общая денежная сумма всех зарегистрированных случаев (Corruption Seriousness). 


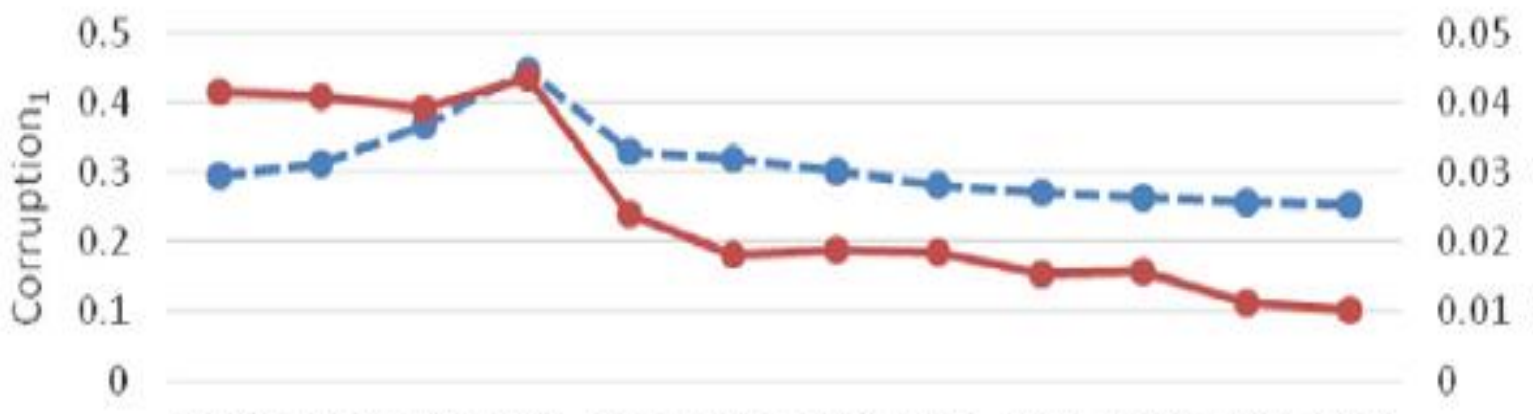

199819992000200120022003200420052006200720082009

$-2=$ Corruption1: the number of registered corrupt cases per 10,000 people Коррупщн 1: чнсло зарегистрнрованных случаев на 10.000 человек

- Corruption2: the sums involved in all registered corrupt cases divided by GDP Коррупия 2: отношенне общей суммы взяток к ВВП

Рисунок 12. Случаи коррупции в Китае в период с 1998 по 2009 г.

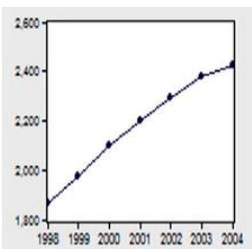

Anhui
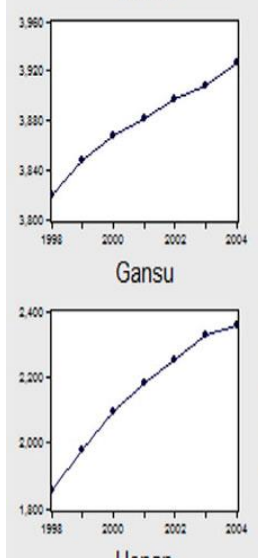

Henan

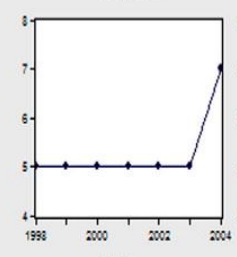

Hainan

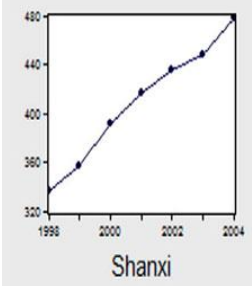

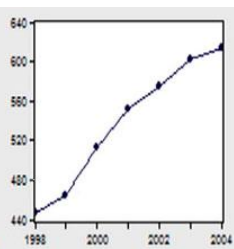

Hubei
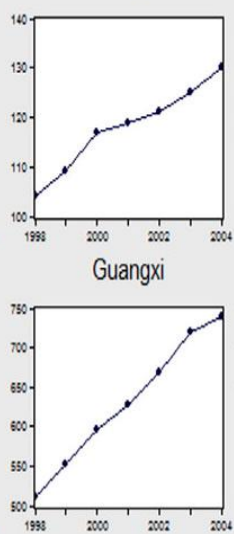

Jilin
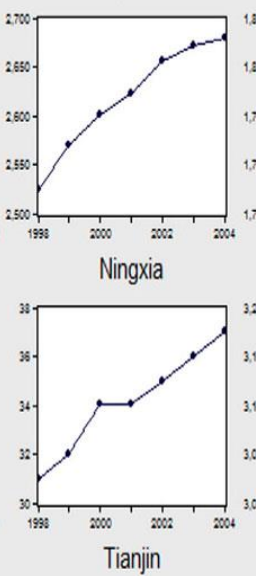

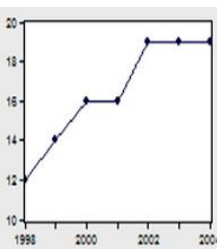

Bejing

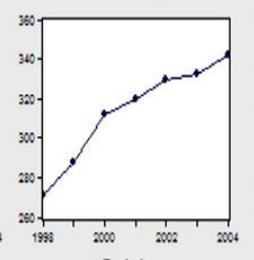

Guizhou

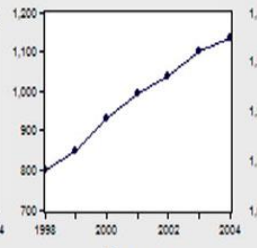

Jiangsu
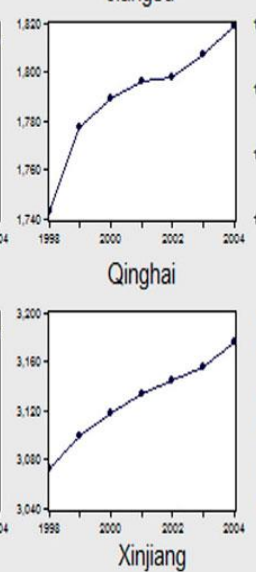

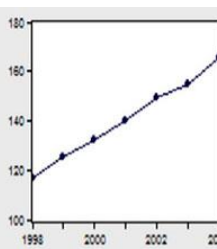

Chongqing
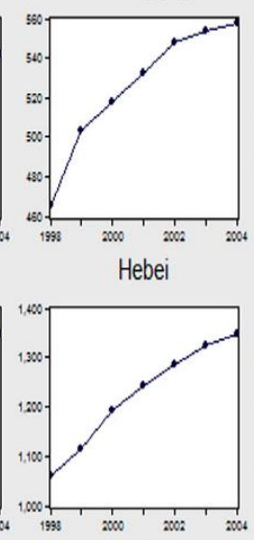

Jiangxi
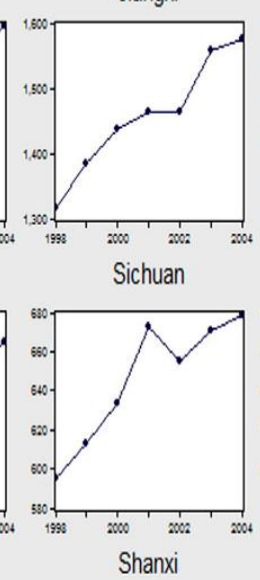

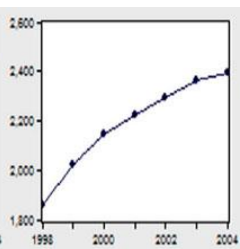

Fujian

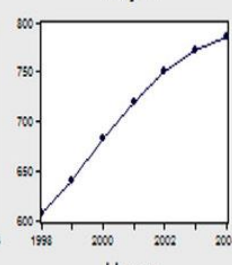

Hunan

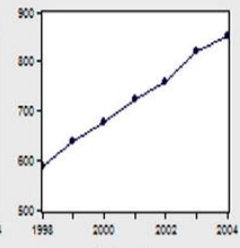

Liaoning

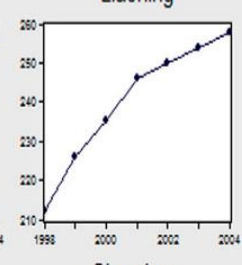

Shandong

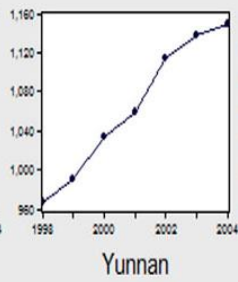

Yunnan

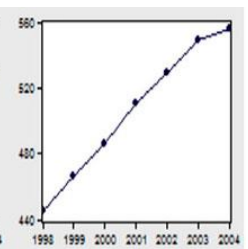

Guangdong
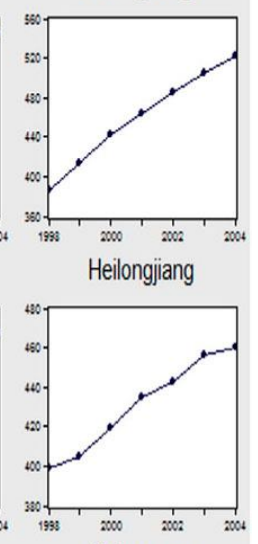

Neimenggu
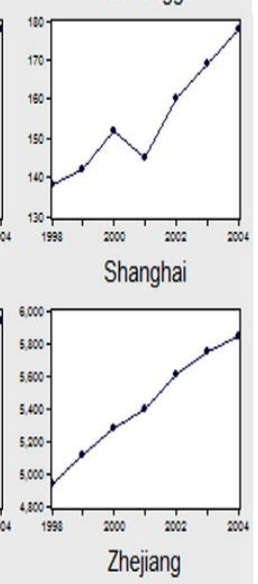

Рисунок 13. Развитие плотности религиозных институтов в провинциях В 1998-2004 гг. 
Религия (или т.н. "религиозная плотность") определялась как число религиозных институтов (мест религиозного культа) в провинции: буддистских монастырей, даосистских храмов, христианских церквей и мусульманских мечетей. Для того, чтобы определить антикоррупционный эффект двух самых влиятельных китайских религий буддизма и даосизма - отдельно была собрана информация о наиболее значимых 141 буддистских монастырях и 21 даосистских храмах.

Уровень правовой среды в провинции измерялся с помощью композитного индекса маркетизации. Индекс маркетизации отображает относительные позиции китайских провинций на пути к рыночной экономике. Таким образом, индекс является сравнительным и не имеет абсолютного значения. Он состоит из 19 значений институциональных преобразований в пяти областях: (1) структура экономики (с уклоном в развитие частного сектора), (2) торговые барьеры между регионами, (3) ценовое регулирование, (4) рынок факторов производства, (5) законодательная среда.

Выводы авторов сформулированы следующим образом:

- Между религией и региональной коррупцией существует отрицательная корреляция. Таким образом, религия выступает неформальным институциональным фактором, сдерживающим распространение коррупции.

- В то же время в провинциях с сильными правоохранительными органами связь между религиозностью населения и коррупцией ослабевает. Это доказывает, что религия и закон - взаимозаменяемые средства предотвращении коррупции.

- Антикоррупционные эффекты традиционных религий Китая - буддизма и даосизма выше, чем христианства и ислама, также распространенных в стране. При этом буддизм имеет больший сдерживающий эффект, в то время как корреляция между даосизмом и уровнем коррупции, хотя и отрицательна, но незначительна.

Выводы исследователей потенциально применимы на практике. В странах с быстро развивающейся экономикой (представителем которых является Китай) и относительно неразвитой правовой системы неформальный институт религии действительно может выступать ограничителем рентоориентированного поведения властей. 


\section{DEMOGRAPHIC DIGEST}

\section{DIGEST IS COMPOSED BY ILYA KASHNITSKY, SOPHIA AKHMANAEVA, ANNA BEZHANISHVILI, NIKITA GANZHA, JULIA LONSHCHIKOVA, AND VADIM KHRUKOV}

- Zhang, J. The Evolution of China's One-Child Policy and Its Effects on Family Outcomes

- Tropf, F. C., \& Mandemakers, J. J. Is the Association Between Education and Fertility Postponement Causal? The Role of Family Background Factors.

- Bongaarts, J., Mensch, B. S., \& Blanc, A. K. Trends in the age at reproductive transitions in the developing world: The role of education

- Wright, D. M., Rosato, M., \& O'Reilly, D. Influence of Heterogamy by Religion on Risk of Marital Dissolution: A Cohort Study of 20,000 Couples

- Reher, D., \& Requena, M. Elderly women living alone in Spain: the importance of having children

- Garcia-Roman, J., Flood, S., \& Genadek, K. Parents' time with a partner in a cross-national context: A comparison of the United States, Spain, and France

- Wahrendorf, M., Akinwale, B., Landy, R., Matthews, K., \& Blane, D. Who in Europe Works beyond the State Pension Age and under which Conditions? Results from SHARE

- Faggian, A., Rajbhandari, I., \& Dotzel, K. R. The interregional migration of human capital and its regional consequences: a review

- $\quad X u, X$., Li, Y., Liu, X., \& Gan, W. Does religion matter to corruption? Evidence from China

ILYA S. KASHNITSKY (ilya.kashnitsky@gmail.com), NATIONAL RESEARCH UNIVERSITY HigHER SCHOOL OF ECONOMICS, RUSSIA; UNIVERSITY OF GRONINGEN (RUG) AND NETHERLANDS INTERDISCIPLINARY DEMOGRAPHIC INSTITUTE (NIDI, NETHERLANDS).

Sophia Akhmanaeva, Anna Bezhanishvili, Nikita Ganzha, Julia Lonshchikova,

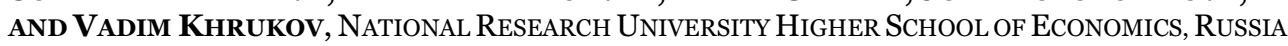

DATE RECEIVED: FEBRUARY 2018. 